supreme. He has no choice but to accept the vocation assigned to Him by the Father whose will is sovereign and whose command is imperative. 'That, which My Father has given to $\mathrm{Me}$ is greater than all things.' This, however, as we have seen, is not the meaning originally intended. The original meaning is represented by the other text, and we have already shewn that the new context suits it decidedly better than does the old.

Furthermore, the rearrangement we suggest makes plain the object

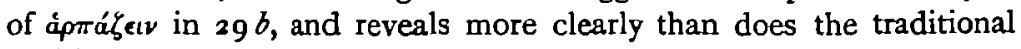
position of verse 29 the motive for the reference to the supreme power of the Father. In verse 18 Jesus declares that no one takes His life away from Him ; He lays it down of His own free will in obedience to the command of His Father. No one could force Him to surrender His life against His will, for $\mathrm{He}$ is in the hand of the all-powerful Father! 'My Father who has given Me the commandment is greater than all, and no one is able to snatch $M e$ out of the Father's hand!' That is the meaning of verse 29. The Shepherd is in the Father's hand, from whence no one can take Him by force! How naturally does verse 30 now follow on verse 29. ' $I$ and the Father are one.' To force Him would be tantamount to forcing the Father-for they are one!

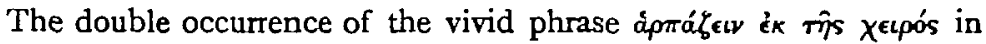
verses 28 and 29 (which perhaps was responsible for the wrong placing of rerses r9-28) does not of necessity involve that it is used both times with the same object or with an identical application. Often in the Fourth Gospel Jesus speaks of the relation of His followers to Himself as being analogous to His own relation to the Father. He so speaks in verses 14,15 of this very chapter: ' I know mine own, and mine own know Me, even as the Father knoweth $\mathrm{Me}$, and I know the Father.' It is quite in accord with Johannine usage for Jesus to say that no one shall snatch His sheep out of His hand, and that no one can snatch Him out of His Father's hand. The double statement brings to mind the great declaration of St Paul in I Cor. iii $23-i \mu \epsilon i s$ X $\delta \dot{e} \oplus \mathbf{c} \mathbf{v}$.

J. Hugh Michael.

\title{
IRISH VERSIONS OF THE VISION OF ST PAUL.
}

THe apocryphal Vision of St Paul, which is probably not earlier than the year 380, is extant in Latin, Greek, Syriac, and Coptic. ${ }^{1}$ But during

1 Latin in M. R. James Apocrypha Anecdota ii; English translation in AnteNicene library (extra vol.). Greek with English translation of Syriac in Tischendorf Apocalypses Apocryphas; English translation of Greek in Ante-Nicene library (vol. xvi). Coptic in Budge Miscellameous Coptic Texts in the Dialect of Upper Egypt. 
the Middle Ages abridged and somewhat altered versions of this attained an extreme degree of popularity, and exercised a considerable influence on the vision-literature of various countries in Europe. H. Brandes, in his Visio Pauli (Halle, r885), has published, besides a German version, two Latin texts which differ in many points from each other, as well as a fragment of a third: for reference sake these may be numbered $\mathrm{A}, \mathrm{B}$, and c. It is also known in Languedoc, Old-French, Danish, Anglo-Saxon, Middle-English, and other vernaculars. We bere deal with a fragment of an Irish version which has not been rendered into English before; as it is so brief we give it in its entirety, the translation being due to Miss Mary E. Byrne, B.A. The original is contained in the Liber Flavus Fergusionum ii fol. $3^{8}$ [47].

'The vision of Paul of the pains of Hell by the permission of God on Sunday, for Sunday is the day of rejoicing and gladness of Heaven, so that for that [it was] chosen for the vision. A question arises here : Who is the first person who prayed for sinners to get respite on Sunday ? Not difficult [the answer]. Paul the Apostle and Michael the Archangel together, when they went to Hell to look at its pains, for God wished Paul to go to look at Hell so that he might see all its pains. He saw first at the door of Hell wooden houses, and the sinners being tortured in them, some of them being suspended by their feet, and another set by their hands, and another by their hair, and another by their tongues, and another by their wrists. And Paul saw then a fiery cave. There were seven flames in it, and a difference of colour on each flame, and many souls being tortured beyond all description in it. And there are six plagues around that cave. The first of them is snow, the second ice, the third fire, the fourth serpents, the fifth fiery lightnings, and the sixth unendurable stench. And then the souls of sinners that did not repent are put to be tortured, and each of them experiences his [special] punishment according to their worldly works. Some of them are weeping, and some sobbing and groaning, and asking for death which they do not get, and others being burnt and asking for death, and they. do not get it at all. What is the reason that they do not get death? Not difficult [the answer]. The souls never die! And it is right that Hell should be dreaded so, [a place] in which there is eternal suffering, and heartsobbing, and gloom without joy, and abundance of tears, and trouble of heart, and sadness unending on account of the suffering of the souls. It is in that place that is the fiery wheel in which are a thousand spokes (lit. pins), and it (the wheel) is a thousand fathoms in depth and breadth ; and the diabolical angels of Hell are every day setting in motion these spokes. There are thousands of souls being perpetually burnt in that cave, and it were enough of pain for all the children of Adam [merely] to get a description of that cave, though they should 
never see it with their eyes. And after that Paul saw the terrible rough stream, in which were abundant hellish reptiles and the horrible poisonousheaded fishes of black Hell, swallowing the souls of the sinners, grinding and chewing them, as wolves through greed and immoderate hunger grind the sheep, and it is thus that the horrible fishes carry off the souls of the sinners, and grind and chew them.'

Here the text breaks off abruptly, as there is something missing from the MS. But enough remains to shew that it corresponds to Brandes's version B, which is also found as Homily too of Bede's Homiliae Subdititiae. But it is far from being a slavish translation. It has a strong Celtic colouring, as shewn e. g. by the introduction of the interrogatory clauses. In some details, too, it differs from the Latin. The wooden houses and the fiery cave of the Irish are represented in B by trees and a fiery furnace respectively. Again, there are only six plagues mentioned in the Irish (the fourth, blood, being omitted) as compared with seven in $B$. Had we the remainder of the Irish no doubt other differences would be found.

But there is another version of the vision, later in date, found in Irish, and apparently peculiar to that language, to which attention must now be directed. Dr Douglas Hyde has published the text of it in his Religious Songs of Connacht vol. ii, and a translation in his Legends of Saints and Sinners p. 97. This appears to have been a fairly popular piece, as it exists not only in Dr Hyde's manuscript, but in two MSS in the Royal Irish Academy (23 I 4..f. 95, and 23 I I 7. f. I37), while its translator alludes (p. 45) to a fragment in the library of University College, Dublin. Though it is so accessible to students a brief analysis must be given here for purposes of comparison.

The apostle Paul is in Smyma, and beseeches God to reveal to him something of the pains of Hell. A youth, the Archangel Michael, comes to him, and conducts him to the death-bed of a sinner. The latter's soul is brought out with pain and difficulty." A dialogue ensues between it and the body; it is then judged by Christ, and condemned to Hell. Paul then desires to see the infernal pains. He is conducted to a deep valley, through which runs a black river. On the far side of this there is a fiery cave and a lake of ice, in which the proud are tormented alternately. Adulterers are gnawed by loathsome reptiles. Avaricious people have fiery mountains thrown down on them. The envious are bound with fiery chains. Gluttons suffer a Tantalus-torture in stinking water. Those who gave way to anger have flames coming out of their

1 Migne P. L. 94 col. 502.

- See an article by the present writer on The Bringing Forth of the Soul in Irish Literature (J.T.S. October 1920). 
mouths, and are beating each other. The slothful people who neglected to hear Mass are bound on filthy beds. St Paul is then taken to Heaven, which is briefly dismissed in a few lines.

It is obvious that this version is a composite one, being built up from such pieces as the description in the Leabhar Breac of the soul's exit from the body, ${ }^{1}$ possibly the Two Deaths, ${ }^{2}$ and the B version of the Vision of St Paul. It has been influenced by the last in a general way. In both a hell-river teeming with monsters is mentioned (of water in Irish, of fire in B); in both occur the torment of alternate ice and fire, the Tantalus-torture, and that of persons being devoured by serpents and worms, though the sins punished are not always the same. The episode of the sinner's soul being carried off by devils, which occurs towards the end of B, may have suggested to the Irish writer the idea of including the lengthy portion which serves as a prelude to the description of the pains of Hell. Finally, the title of the piece, and the account of the Archangel Michael acting as guide, are of course derived from the earlier forms of the vision. On the other hand the mention of a fiery cave at the commencement of Hell connects this version with that Irish free translation of $\mathrm{B}$ which we have given above. It may be that the author of the version which is in Saints and Sinners may have used an Irish text rather than a Latin one.

The popularity of Dr Hyde's version is also shewn by the use made of it in a later document, the Vision of Merlino, which has been edited and translated by Prof. R. A. S. Macalister. ${ }^{3}$ There are several points of connexion between both, viz. the classification of the seven deadly sins, the punishments for gluttony and sloth, and the inclusion of a list of the epithets of Hell. The phraseology, too, is similar : in Hyde's Paul the expression 'the fiery hearth of pains' occurs several times; it is found once in Merlino, which last has, however, a corresponding phrase, 'the dwelling of pains'. A remarkable connecting-link between the two is found in the MS 23 I 17 . After the words 'the angel brought him to the brink' (Hyde, p. 104) that manuscript inserts a brief description of the city of Pluto, fair without but full of torment within, which exactly corresponds to the palace of Plutando into which Merlino and his companion in crime enter unsuspectingly.

So much has been said with respect to two Irish versions, one of which is fragmentary, the other late. But when we bear in mind the widespread influence that the Vision of St Paul exerted on European

1 Atkinson Passions and Homilies from L. Breac p. 507.

- Erriu v p. Iat.

S In Zeit. für Celt. Phil. vol. iv, and as a separate publication (M. H. Gill, Igo6). I am indebted to its editor for drawing my attention to it by sending me 2 copy. In a letter he considers it to be of the seventeenth century. 
vision-literature we cannot but believe that versions of it were known to Irish writers from an early date, and coloured their descriptions of the Other-World to a marked degree. Accordingly we adduce some passages which appear to shew traces of this influence.

In the first place the Vision appears to be expressly mentioned twice in the Vision of Adamnan, where the allusions to St Paul's experiences in the Unseen World, and his preaching with respect to the same, evidently relate to the apocryphal work, and not to anything in the New Testament.

The earlier portion of Hyde's version is taken up with the bringing forth of the evil soul, and its judgement by Christ. Nothing to correspond to this is found in Brandes's A, B, or C, except the brief passage in the second, already alluded to, which describes the sinner's soul being carried off by devils. But it is worthy of note that in the oldest versions this episode occupies a prominent place; the soul is brought out of the body by evil angels (who do it with severity, Syriac), brought to judgement before God (also shewn the vision of God, Latin), condemned, and given over to punishment. Then after the trial of another soul the contents of the Other-World are revealed to St Paul.

In various places in Irish literature, e.g. in the Vision of Adamnan, the Voyage of the Ua Corra, and the Cain Domnaig (Ériu ii), there occurs the belief that a weekly respite from pain is granted to the souls in Hell. This conception is, of course, widespread, being found in Prudentius and St Augustine, while it also appears in Hebrew and Coptic; though it is possible that it was introduced into Irish literature through the medium of the Vision of St Paul, where it occurs in both the old and the mediaeval texts. In an Irish version of the Transitus Mariae, ' as yet unpublished, this respite is represented as being due to the intercession of the Virgin after she had been shewn Hell, which evidently implies an acquaintance on the part of Irish writers with the Greek Apocalypse of the Virgin.

In the Vision of Merlino (as translated in Z.C.P.) unchaste women have devils sucking at their breasts. A similar incident occurs in a Middle-English version of the Vision of Paul, and is obviously connected with the passages in the Vision of Esdras, and in the much earlier Apocalypse of Peter. Whether this last work was known in Ireland is an interesting question not easy to answer.

Some minor points nay now be noticed. In the Vision of Tundal, written by an Irish monk at Ratisbon in 1149 , the visionary sees the Devil in Hell as a many-handed monster swallowing souls. This is

1 This has been dealt with by the present writer in this Jourkal for October 1921.

I In E. E.T.S. Original Series, xlix p. I5I. 
based on a conception which runs through earlier Irish writings, though it is possible that all these have been influenced by the description of the hundred-headed fiery dragon Parthemon in Brandes's version A, in whose mouth sinners are placed. In the older Latin version the description of the reception by the angels of the good and evil soul respectively, and the vision of God shewn to the latter, form a general parallel to the events that occur in the last of the Seven Heavens in the Vision of Adamnan, though there is evidence to shew that the whole episode of the Seven Heavens included in that vision is not peculiar to Ireland at all, but is derived from an external source. ${ }^{1}$ Again, in the older Latin version St Paul looks back from the height of Heaven, and sees a great fire spread over the whole world; this resembles the incident in the vision of St Fursa where the saint, lifted up on high, looks downward, and sees four fires which subsequently unite into one.

In conclusion, it is clear that the mediaeval versions of the Vision of St Paul were known in Ireland from an early date. Indeed, it could hardly be otherwise, when we realize the great popularity of the piece, as well as its use by the Anglo-Saxon Church, ${ }^{8}$ the theological literature of which contains so many parallels to the Irish. It may be that some student, better acquainted with the contents of Irish MSS than the present writer, may be able to indicate a complete text. That the very. oldest versions (especially the Latin) were studied in Ireland seems also probable.

St John D. Seymour.

\section{SOME TECHNICAL TERMS OF GREEK EXEGESIS.}

IT has been said that the inheritance of Origen was divided into two parts, one of which passed to Alexandria and the other to Antioch; that his Platonism in thought and his allegorical interpretation of the Bible formed the Alexandrian share, while his critical activity and his devotion to the actual text of Scripture were maintained and continued by the scholars of Antioch. This statement, however, calls for one important qualification. It should be remembered that the tradition of Antiochene learning was from the earliest times connected with Aristotle and the rhetoricians, just as the tradition of Alexandria was

1 An article on this subject by the present writer will appear in a forthcoming number of the Zeit. für Calt. Phil.

2 The attitude of the Anglo-Saxon Homilist Aelfric towards the Vision is noteworthy. He asks indignantly, 'How do some men read the false composition; which they call the Lision of St Paul, when he himself said that he heard the secret words, which no earthly man may speak ?' 